\title{
A Study on the Intention of Public Institution Managers and Procurement Business Bidding Managers to Use the e- Procurement System
}

\author{
Kil-hwan Shin ${ }^{1}$, Choon Yeul Lee ${ }^{2}$ and Woon-heok Ko ${ }^{3 *}$ \\ ${ }^{1}$ LIG System \\ ${ }^{2}$ Kookmin University, Graduate School of Business IT \\ ${ }^{3}$ Public Procurement Service \\ ${ }^{1}$ khshin25@naver.com, ${ }^{2}$ cylee@kookmin.ac.kr, ${ }^{3}$ whko337@naver.com
}

\begin{abstract}
This study analyzes the difference in the intention to use an e-Procurement system by examining public institution procurement managers and the bidding managers of procurement businesses who participate in government bids. A comparison of intention of use between procurement institutions and procurement businesses showed that the influence on the intention to use among public institution procurement managers was stronger than was that on procurement business bidding managers. The results also showed that public institution procurement managers had a stronger influencing relationship with social influence, task-technology fit, partnership, and security variables; the factors and functions related to these must be strengthened in order to revitalize the e-Procurement system. Meanwhile, procurement business bidding managers had a strong relationship with the facilitating condition and technological characteristic variables. This study is significant in showing the importance of strengthening the functions related to security.
\end{abstract}

Keywords: UTAUT, TTF, behavioral intention, security, e-Procurement, Online Service

\section{Introduction}

The e-Government process is an online service or information procurement method that uses information technology such as the Internet or other electronic means to improve the responsibility, transparency effects, and efficiency of government and public organizations [1]. Among these e-Government systems, no single channel offers detailed procurement information on bidding that can be used for procurement administration tasks. Therefore, the required documents must be submitted in person, resulting in the inconvenience of having to assess the bids and procurement information for each institution each time [1]. A national marketplace (G2B) system is being built by connecting and combining all institutions in order to resolve this issue, and innovative procurement tasks are being handled online. The Public Procurement Service recently started running a seamless e-Procurement administration and now offers various services such as smartphone fingerprint bidding services to provide a ubiquitous, next-generation e-Procurement system. This is a next-generation e-Procurement system operating through several enhancements that consider transparency and efficiency as important facilitating factors in procurement [2].

This study investigates whether there is a significant difference in intention to use between public institution procurements managers who procure businesses and

* Corresponding Author : Woon-heok Ko 
procurement business bidding managers who take part in bidding by using the Keil et. al., [3] moderating effect analysis, taking the e-Procurement system as the subject. The study presents working-level implications and seeks to determine how best to revitalize the eProcurement system.

The next-generation national marketplace is being enhanced to offer system transparency and efficiency, important facilitating factors for seamless procurement administration. Developments since 2014 have resulted in an e-Procurement system that offers the procurement support services of public Informatization businesses.

\section{Research Model and Data Analysis}

\subsection{Research Model}

We analyze the acceptance factors of procurement business users for the eProcurement system by examining TTF, partnership, and security factors as well as job crafting competence variables based on the UTAUT in Venkatesh et. al., [4] to establish the study model shown in Figure 1.

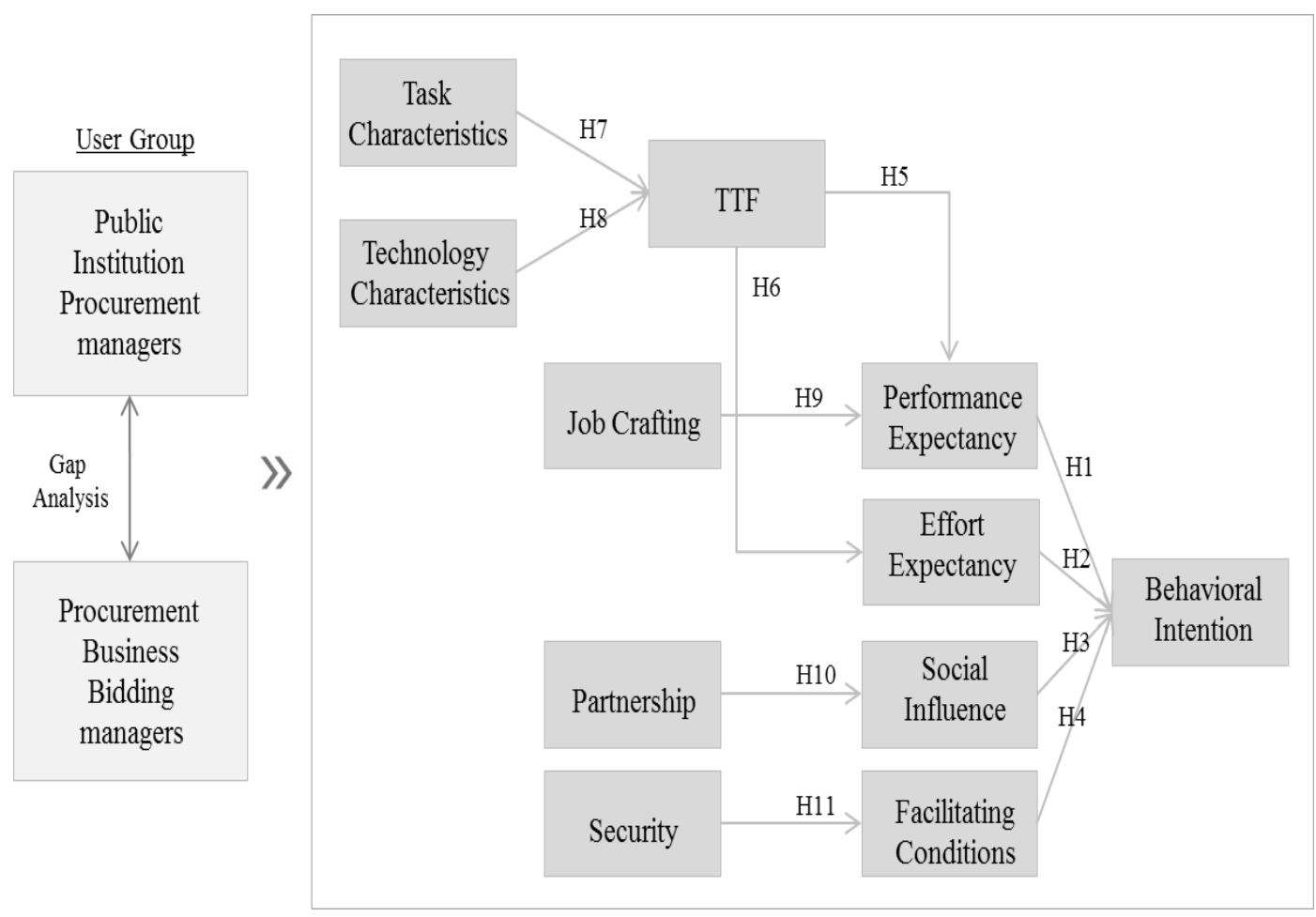

Figure 1. Research Model

The UTAUT (Unified Theory of Acceptance and Use of Technology) is a model created by combining eight different theories and models of information technology, including the Theory of Reasoned Action (TRA), Theory of Planned Behavior (TPB), Technology Acceptance (TAM), Unified TAM-TPB model, Motivational Model (MM), Model of PC Utilization (MPCU), Innovation Diffusion Theory (IDT), and the Social Cognitive Theory (SCT). The UTAUT model is composed of four key concepts: performance expectance (PE), effort expectance (EE), social influence (SI), and facilitating conditions (FC). It also includes moderating variables such as age, gender, experience, and voluntary participation [4].

The TTF (Task Technology Fit) is the degree of harmony between the capability of information technology and task demands specifically, the capability of the information 
technology used to support tasks within an organization [5]. Information technology that fits the task characteristics and direction is accepted and helps improve the results. Good TTF capability promotes the acceptance of information technology among users, while poor TTF for complex tasks will reduce technology acceptance among users. For example, although mobile banking systems can be used anywhere at any time in this ubiquitous era, users will continue to prefer traditional online banking services if they remain in their office or if they are in an environment where there is no demand for mobile payments. The TTF model uses the TAM and UTAUT models from the perspective of acceptance among information technology users; this is being investigated by many studies in various fields [6]. The results of [6] offer empirical proof that models that combine the UTAUT and TAM (information technology acceptance models) with the TTF model (i.e., TAM or UTAUT + TTF) have greater explanatory power and provide deeper insight than when the models are used individually.

\subsection{Definition of Research Variables}

The research variables are defined as shown in (Table 1). They are extracted by reviewing variables used in previous studies.

Table 1. Research Variables

\begin{tabular}{|c|c|c|}
\hline Factor & Variables & Source \\
\hline $\begin{array}{l}\text { Performance } \\
\text { expectancy }\end{array}$ & $\begin{array}{l}\text { Usefulness } \\
\text { Improved Work Productivity } \\
\text { Easy Work Process } \\
\text { Usefulness of Evidence }\end{array}$ & $\begin{array}{l}\text { V. Venkatesh, } \\
\text { M.G. Morris and } \\
\text { G.B. Davis (2003) }\end{array}$ \\
\hline Effort expectancy & $\begin{array}{l}\text { Adaptability } \\
\text { Easy Cognition of Use } \\
\text { Work Applicable Convenience } \\
\text { Easy Learning } \\
\text { Based Technology Availability }\end{array}$ & $\begin{array}{l}\text { V. Venkatesh, } \\
\text { M.G. Morris and } \\
\text { G.B. Davis (2003) }\end{array}$ \\
\hline Social influence & $\begin{array}{l}\text { Recommended Intention } \\
\text { Extent of Convenience Awareness } \\
\text { Awareness of Availability } \\
\text { Use Intention and Desire } \\
\text { Popular Generality }\end{array}$ & $\begin{array}{l}\text { V. Venkatesh, } \\
\text { M.G. Morris and } \\
\text { G.B. Davis (2003) }\end{array}$ \\
\hline Facilitating Conditions & $\begin{array}{l}\text { Organizational support } \\
\text { Retention of knowledge } \\
\text { Business Support } \\
\text { Compatibility of Business processing } \\
\text { style }\end{array}$ & $\begin{array}{l}\text { V. Venkatesh, } \\
\text { M.G. Morris and } \\
\text { G.B. Davis (2003) }\end{array}$ \\
\hline Task Characteristics & $\begin{array}{l}\text { Accuracy of business promotion } \\
\text { Repeatability of proposal task } \\
\text { Management of SW business } \\
\text { Share of business information }\end{array}$ & $\begin{array}{l}\text { Tao Zhou, Yaobin } \\
\text { Lu and Bin } \\
\text { Wang(2010) } \\
\text { Goodhue \& } \\
\text { Thompson(1995) }\end{array}$ \\
\hline
\end{tabular}




\begin{tabular}{|c|c|c|}
\hline $\begin{array}{l}\text { Technology } \\
\text { Characteristics }\end{array}$ & $\begin{array}{l}\text { Function of proposal task } \\
\text { Function of business mgmt. } \\
\text { Function of User Interface } \\
\text { Prompt real-time service }\end{array}$ & $\begin{array}{c}\text { Tao Zhou, Yaobin } \\
\text { Lu and Bin } \\
\text { Wang(2010) } \\
\text { Goodhue \& } \\
\text { Thompson(1995) }\end{array}$ \\
\hline Task TechnologyFit & $\begin{array}{l}\text { Adequacy of proposal task } \\
\text { Adequacy of business Mgmt. } \\
\text { Adequacy of internet business } \\
\text { environment } \\
\text { Adequacy of e-procurement service }\end{array}$ & $\begin{array}{c}\text { Tao Zhou, Yaobin } \\
\text { Lu and Bin } \\
\text { Wang(2010) } \\
\text { Goodhue \& } \\
\text { Thompson(1995) } \\
\text { Dishaw \& } \\
\text { Strong(1999) }\end{array}$ \\
\hline Partnership & $\begin{array}{l}\text { Expectancy of resource sharing } \\
\text { interdependence } \\
\text { degree of trust } \\
\text { cooperation of information business }\end{array}$ & Khan, K.B(1996) \\
\hline Security & $\begin{array}{l}\text { Safety of Internet Security } \\
\text { Safety of Information Infringement } \\
\text { Safety for Data Leakage } \\
\text { Work Performance Safety }\end{array}$ & $\begin{array}{l}\text { S. H. Jeon, N. L. } \\
\text { Park and J. J. Lee } \\
\text { (2011) }\end{array}$ \\
\hline $\begin{array}{l}\text { Job Crafting } \\
\text { Competency }\end{array}$ & $\begin{array}{l}\text { Increase of structural business support } \\
\text { Decrease of negative business support } \\
\text { Increase of social business support } \\
\text { Increase of challenging task requirement }\end{array}$ & $\begin{array}{l}\text { Tims, M., and } \\
\text { Bakker, A.B } \\
\quad(2010)\end{array}$ \\
\hline Behavioral Intention & $\begin{array}{l}\text { Use Intention Level } \\
\text { Unconscious Use Awareness } \\
\text { Future Use Planning } \\
\text { Expendability Acceptance Level }\end{array}$ & $\begin{array}{l}\text { V. Venkatesh, } \\
\text { M.G. Morris and } \\
\text { G.B. Davis (2003) }\end{array}$ \\
\hline
\end{tabular}

\subsection{Hypotheses}

In this study, 11 hypotheses are established to examine the behavioral intention between for public Institution procurement managers and Procurement Business bidding managers.

[Hypothesis-1] Performance Expectancy has a positive impact to Behavioral Intention of e-Procurement System.

[Hypothesis-2] Effort Expectancy has a positive impact to Behavioral Intention of eProcurement System.

[Hypothesis-3] Social Influence has a positive impact to Behavioral Intention of eProcurement System.

[Hypothesis-4] Facilitating Conditions has a positive impact to Behavioral Intention of e-Procurement System.

[Hypothesis-5] TTF has a positive impact to Performance Expectancy.

[Hypothesis-6] TTF has a positive impact to Effort Expectancy.

[Hypothesis-7] Task Characteristics has a positive impact to TTF. 
[Hypothesis-8] Technology Characteristics has a positive impact to TTF.

[Hypothesis-9] Job Crafting has a positive impact to Performance Expectancy.

[Hypothesis-10] Partnership has a positive impact to Social Influence.

[Hypothesis-11] Security has a positive impact to Facilitating Conditions.

\subsection{Data Analysis Results and Hypothesis Testing}

Data were collected from public institution procurement managers and procurement business bidding managers who will use the e-Procurement system. The results of the positive analysis, organized based on the research hypotheses, are summarized in Table 2.

Table 2. Research Hypothesis Verification Results for public Institution Procurement Managers and Procurement Business Bidding Managers

\begin{tabular}{|c|c|c|c|c|c|c|c|c|c|}
\hline \multirow{2}{*}{\multicolumn{2}{|c|}{ Hypothesis }} & \multicolumn{4}{|c|}{$\begin{array}{c}\text { Public Institution Procurement } \\
\text { Managers }\end{array}$} & \multicolumn{4}{|c|}{$\begin{array}{c}\text { Procurement Business Bidding } \\
\text { Managers }\end{array}$} \\
\hline & & \multirow{2}{*}{$\begin{array}{l}\text { Path } \\
0.018\end{array}$} & \multirow{2}{*}{$\begin{array}{c}\begin{array}{c}\mathrm{t}- \\
\text { value }\end{array} \\
0.171\end{array}$} & \multirow{2}{*}{$\begin{array}{c}\begin{array}{c}\mathrm{p}- \\
\text { value }\end{array} \\
0.865\end{array}$} & \multirow{2}{*}{$\begin{array}{l}\text { Category } \\
\text { Dismissed }\end{array}$} & \multirow{2}{*}{$\begin{array}{c}\text { Path } \\
0.203^{*}\end{array}$} & \multirow{2}{*}{$\begin{array}{c}\begin{array}{c}\mathrm{t}- \\
\text { value }\end{array} \\
1.920\end{array}$} & \multirow{2}{*}{$\begin{array}{c}\begin{array}{c}\mathrm{p}- \\
\text { value }\end{array} \\
0.055\end{array}$} & \multirow{2}{*}{$\begin{array}{l}\text { Category } \\
\text { Adopted }\end{array}$} \\
\hline $\mathrm{H} 1$ & $\begin{array}{l}\text { PEE- } \\
>\text { UBI }\end{array}$ & & & & & & & & \\
\hline $\mathrm{H} 2$ & $\begin{array}{l}\text { EFE- } \\
>\text { UBI }\end{array}$ & $0.284 \dagger$ & 3.531 & 0.000 & Adopted & 0.121 & 1.482 & 0.139 & Dismissed \\
\hline $\mathrm{H} 3$ & $\begin{array}{c}\text { SOI- } \\
>\text { UBI }\end{array}$ & $0.434 \dagger$ & 4.577 & 0.000 & Adopted & $0.271^{* *}$ & 2.278 & 0.023 & Adopted \\
\hline $\mathrm{H} 4$ & $\begin{array}{l}\text { FAC- } \\
>\text { UBI }\end{array}$ & $0.140^{*}$ & 1.855 & 0.064 & Adopted & $0.242 * *$ & 3.039 & 0.002 & Adopted \\
\hline H5 & $\begin{array}{l}\text { TTF- } \\
>\text { PEE }\end{array}$ & $0.681 \dagger$ & 12.061 & 0.000 & Adopted & $0.662 \dagger$ & 11.203 & 0.000 & Adopted \\
\hline H6 & $\begin{array}{l}\text { TTF- } \\
>\text { EFE }\end{array}$ & $0.760 \dagger$ & 20.009 & 0.000 & Adopted & $0.684 \dagger$ & 12.411 & 0.000 & Adopted \\
\hline $\mathrm{H} 7$ & $\begin{array}{l}\text { TAC- } \\
>\text { TTF }\end{array}$ & $0.201 \dagger$ & 3.839 & 0.000 & Adopted & 0.068 & 1.103 & 0.271 & Dismissed \\
\hline H8 & $\begin{array}{l}\text { TEC- } \\
>\text { TTF }\end{array}$ & $0.702 \dagger$ & 14.764 & 0.000 & Adopted & $0.739 \dagger$ & 15.592 & 0.000 & Adopted \\
\hline H9 & $\begin{array}{l}\text { JOB- } \\
>\text { PEE }\end{array}$ & $0.164 * *$ & 2.515 & 0.012 & Adopted & $0.156^{* *}$ & 2.217 & 0.027 & Adopted \\
\hline H10 & $\begin{array}{l}\text { PTS- } \\
>\text { SOI }\end{array}$ & $0.443 \dagger$ & 6.795 & 0.000 & Adopted & $0.421 \dagger$ & 5.982 & 0.000 & Adopted \\
\hline
\end{tabular}




\begin{tabular}{|c|c|c|c|c|c|c|c|c|c|}
\hline H11 & $\begin{array}{l}\text { SEC- } \\
>\text { FAC }\end{array}$ & $0.607 \dagger$ & 11.185 & 0.000 & Adopted & $0.539 \dagger$ & 8.313 & 0.000 & Adopted \\
\hline
\end{tabular}

Table 2 shows that the factors influencing the intention to use e-Procurement systems differ between public institution procurement managers and procurement business bidding managers. The degrees of influence also differ.

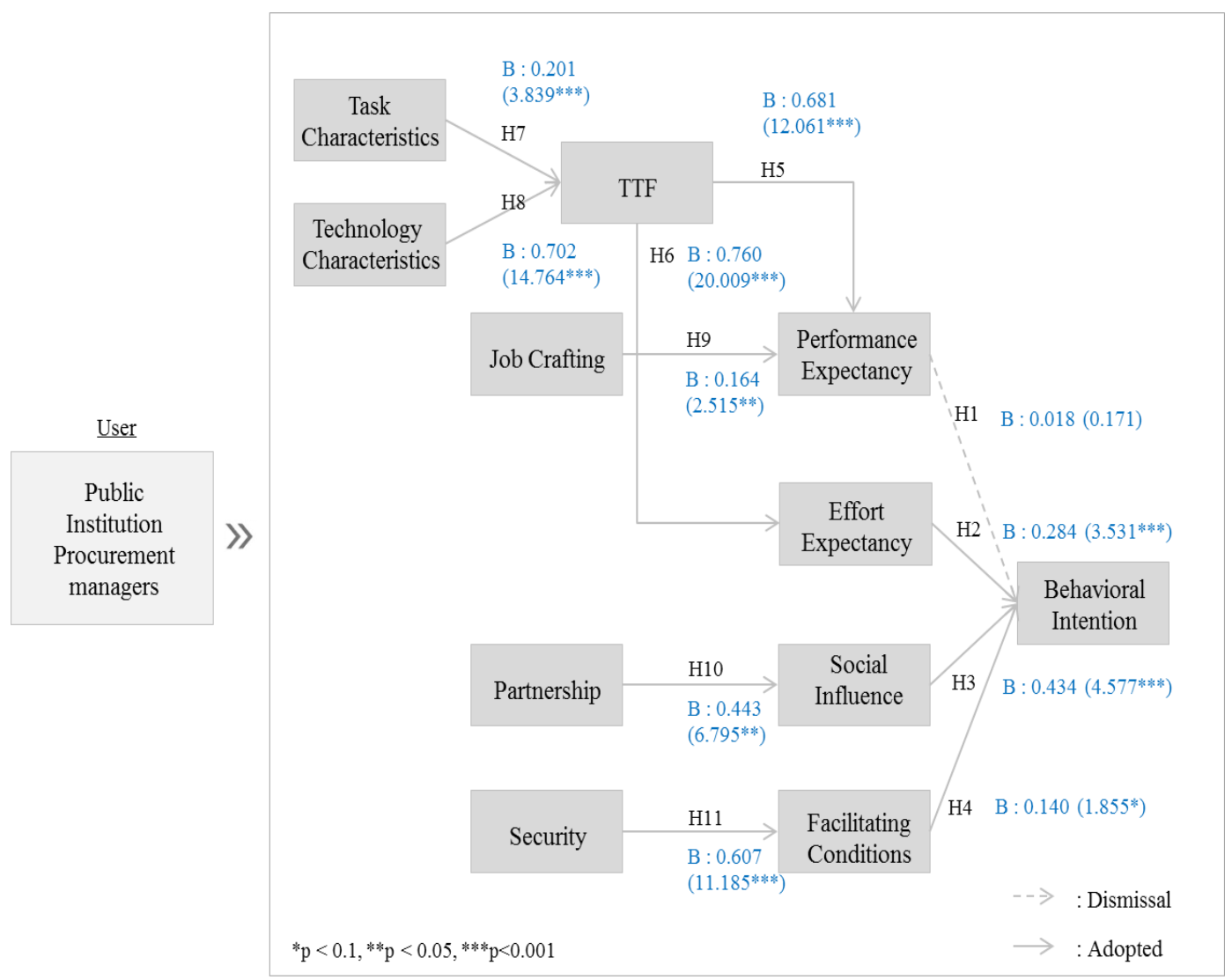

Figure 2. Analysis Result of Public Institution Procurement Managers

For the procurement managers of public institutions, performance expectance was the only factor that had no significant influence on intention to use. For the bidding managers of procurement businesses, effort expectance was the only factor that had no significant influence on intention to use. For procurement business bidding managers, the TAC factor (explaining the TTF) was dismissed. Therefore, we used the Keil et. al., (2000) adjustment effect analysis method to see if this difference and degree of influence was significant and analyzed the validity of the difference. An adjustment effect is the process of checking a variable's degree of explanatory power in a model. 


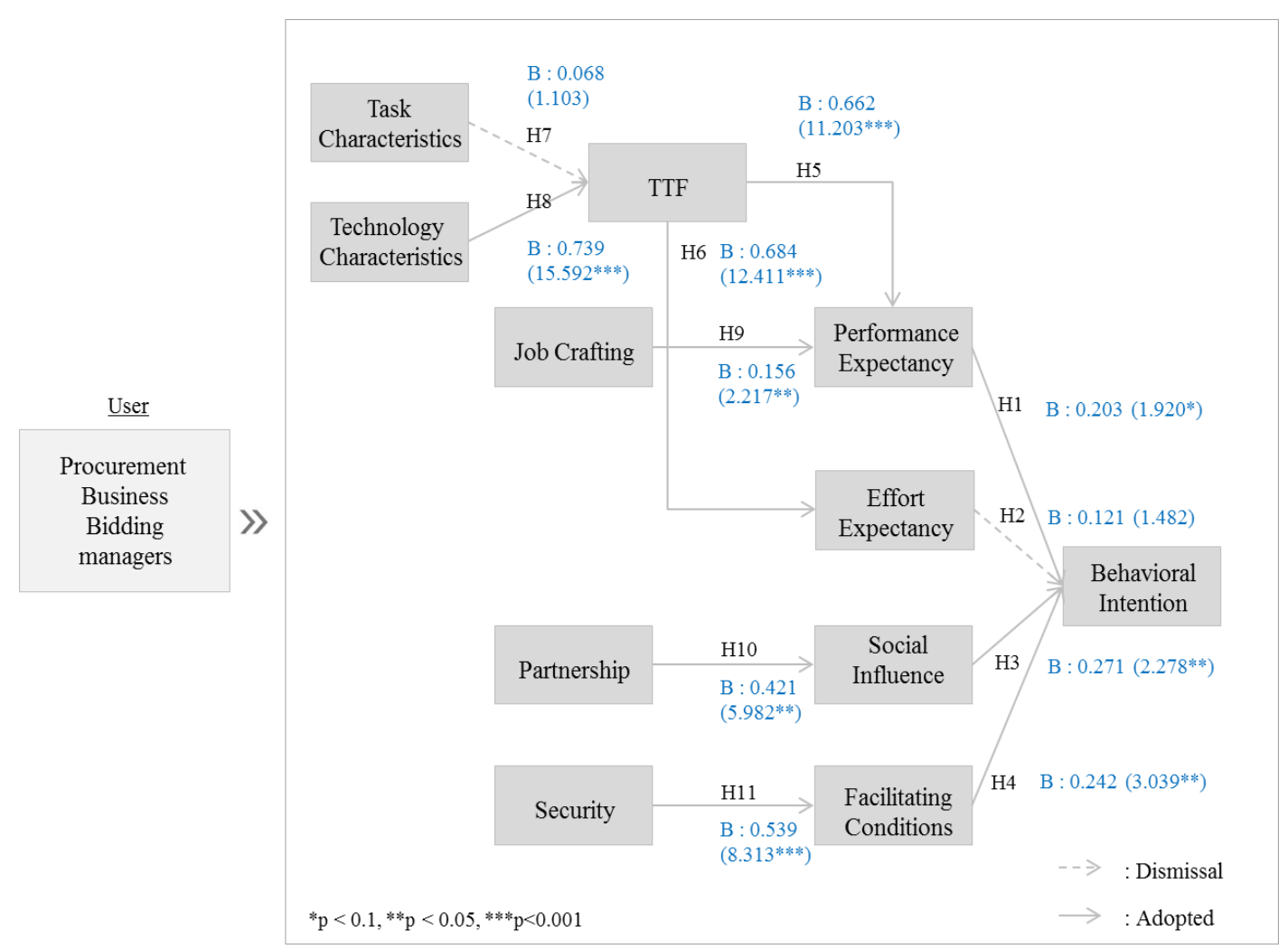

Figure 3. Analysis Result of Procurement Business Bidding Managers

\begin{tabular}{|c|c|c|}
\hline 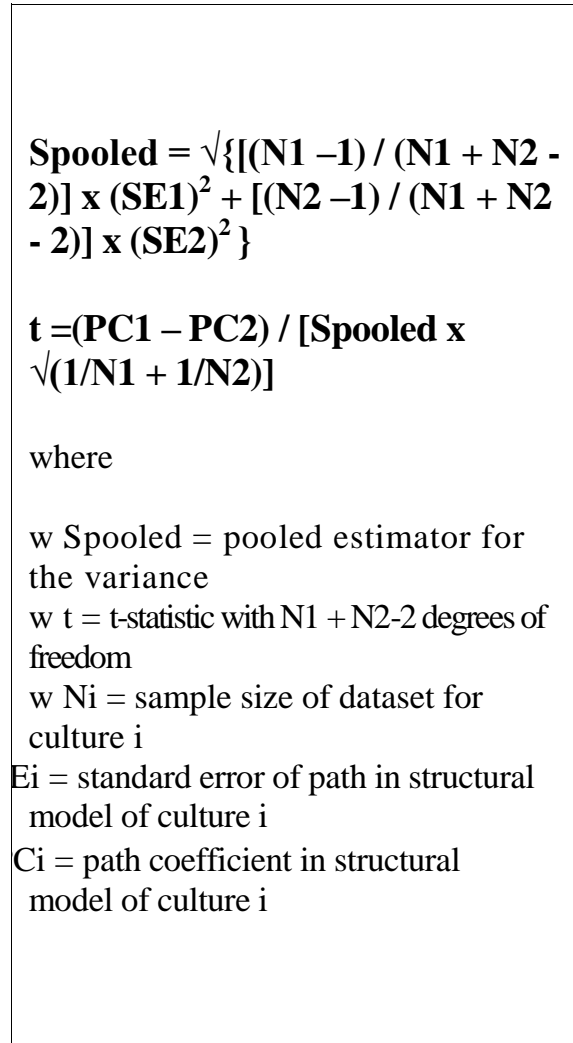 & $\begin{array}{c}\Rightarrow \\
\text { (Application) }\end{array}$ & 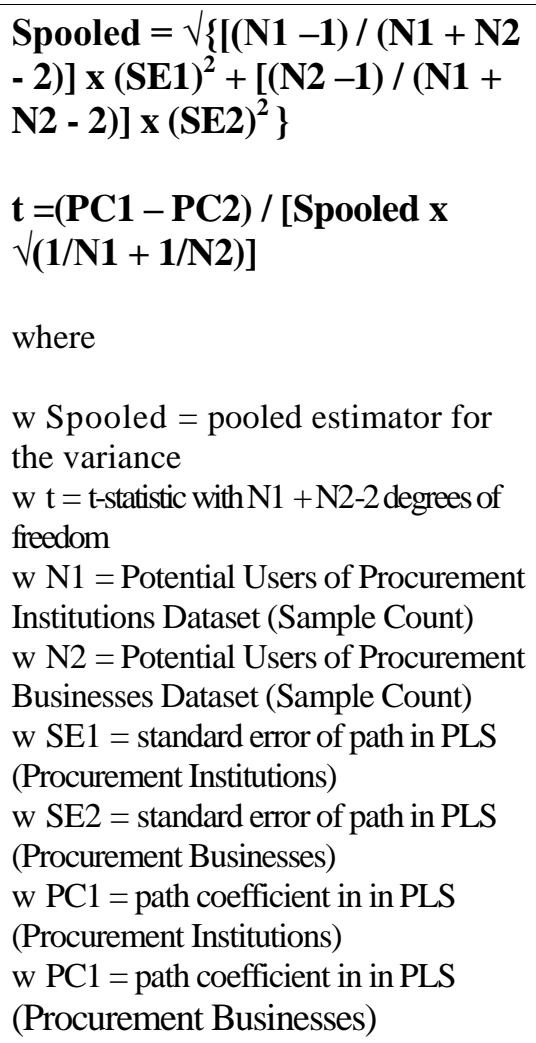 \\
\hline
\end{tabular}

Figure 4. Keil's Adjustment Effect Verification Formula 
The Keil et. al., (2000) adjustment effect verification is strong between independent variables and also establishes the theoretical relationship between independent and dependent variables when there are variables with uncertain degrees of influence. The formula is shown in Figure 4.

Table 3 shows the adjustment effect verification results regarding the intention to use the e-Procurement system between public institution procurement managers and procurement business bidding managers. The Keil et. al., (2000) adjustment effect verification measured the differences in the variables' influencing relationships between the public Institution procurement managers and procurement business bidding managers.

Table 3. Adjustment Effect Verification Results between Public Institution Procurement Managers and Procurement Business Bidding Managers

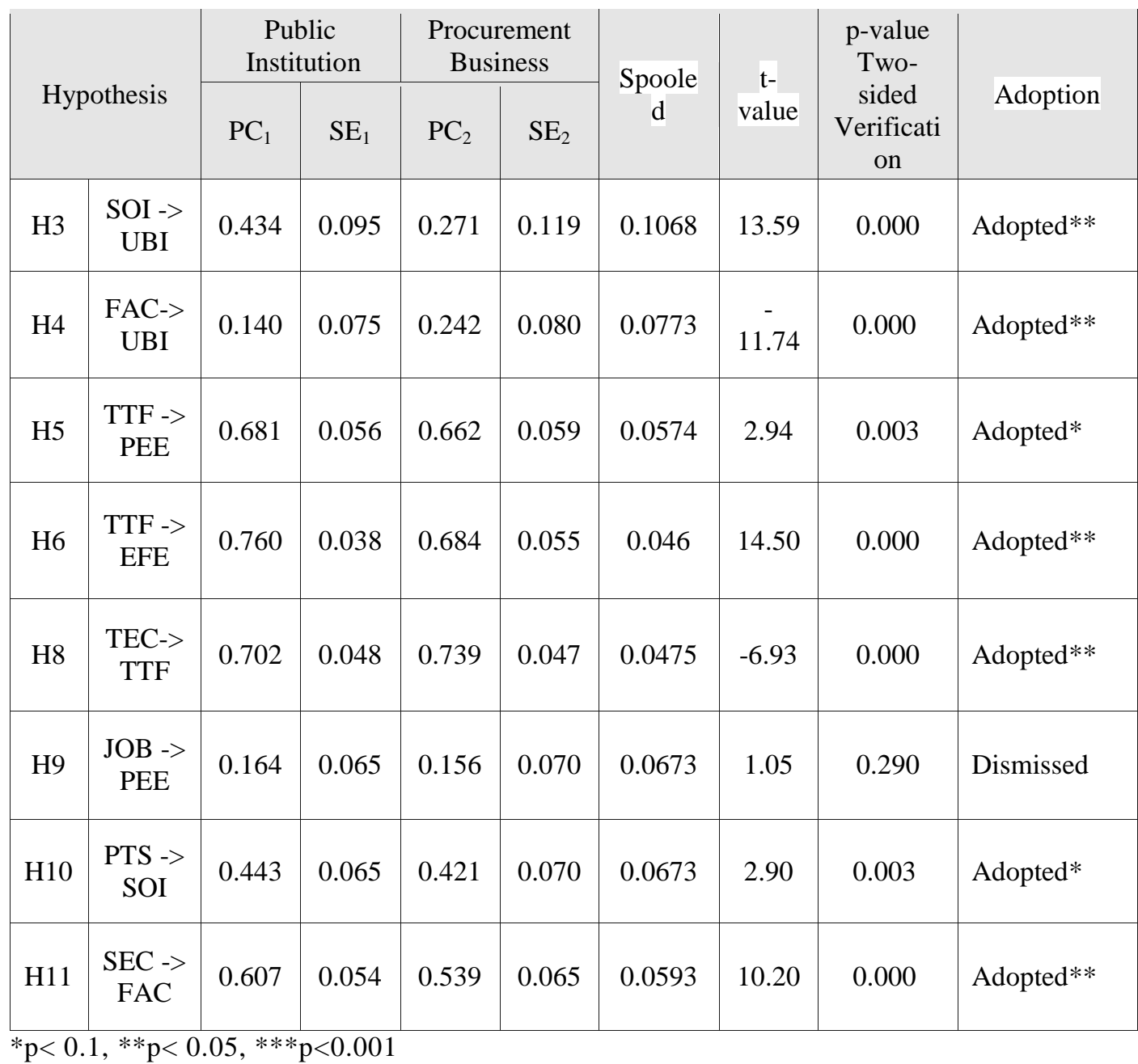

The results show that hypotheses $3,4,6$, and 8 were statistically significant at a 0.001 significance level and that hypotheses 5 and 10 displayed a statistically significant difference between the two groups at a 0.01 significance level. However, the differences in hypothesis 9 , between the influences of the job crafting and performance expectance variables, are not significant.

Specifically, the social influence (SOI), TTF, partnership (PTS), and security (SEC) factors influence the potential users of procurement institutions more strongly than they do the potential users of procurement business organizations. Facilitating conditions (FAC) and technological characteristics (TEC) influence the intention to use of potential procurement business organization users much more strongly than they influence 
potential procurement institution organization users. Therefore, we must determine which factors the two groups consider most important and reflect them in the system.

Revitalizing e-Procurement systems for procurement institutions requires that we consider social influence factors and system convenience, utilize generated information, and increase intention to use. We must also consider the characteristics of the tasks performed by procurement managers and apply TTF criteria combined with the required technology. Furthermore, we must pay more attention to FAC and TEC than to procurement institutions when seeking to revitalize e-Procurement services for procurement businesses. Employing systems using the FAC of procurement businesses will enable us to incorporate important operational features into the system such as levels of organizational help, task knowledge, and technical help desks and thus ensure system revitalization.

\section{Conclusion}

This study used the difference analysis method of Keil et. al., (2000) to measure the degrees of influence among several variables in examining the differences between procurement institutions and procurement businesses with regard to intention to use an eProcurement system. The influence on the intention to use of public institution procurement managers was stronger than was the influence on procurement business bidding managers.

The verification results were at a 99.9\% ( $\mathrm{p}<0.001)$ level for the eight hypotheses tested in this study. In revitalizing an e-Procurement system for public institution procurement managers, social influence, TTF, partnership, and security variables as well as related factors and functions must be strengthened. For procurement business bidding managers, addressing facilitating conditions and technological characteristics as well as strengthening security functions will facilitate user acceptance and revitalize the eProcurement system.

\section{References}

[1] A. Muir and C. Oppenheim, "National information policy developments worldwide in electronic government", Journal of Information Science, vol. 28, (2002), pp. 173-186.

[2] C. Seung-Eun and K. Hyo-Geun, "A study on the development of e-transformation level evaluation model for corporations", Business Informatics Research, vol. 15, (2005), pp. 219-239.

[3] M. Keil, B. C. Y. Tan, K. K. Wei, T. Saarinen, V. Tuunaien and A. Wassenaar, "A cross-cultural study on escalation of commitment behavior in software projects", MIS Quarterly, vol. 24, (2000), pp. 299324.

[4] V. Venkatesh, M. G. Morris and G. B. Davis, "User acceptance of information technology: Toward a unified view”, MIS Quarterly, vol. 27, (2003), pp. 425-478.

[5] M. T. Dishaw and D. M. Strong, "Extending the Technology Acceptance Model with Task Technology Fit constructs", Information and Management, vol. 36, (1999), pp. 9-21.

[6] W. J. Ketiiinger, V. Grover, S. Guha and A. H. Segars, "Strategic information systems revisited: A study in sustainability and performance", MIS Quarterly, vol. 8, (1994), pp. 31-58.

[7] T. Zhou, Y. Lu and B. Wang, "Integrating TTF and UTAUT to explain mobile user adoption", Computers in Human Behavior, vol. 26, (2010), pp. 760-767.

[8] D. L. Goodhue and R. L. Thompson, "Task Technology Fit and Individual Performance", MIS Quarterly, vol. 19, no. 2, (1995), pp. 213-236.

[9] M. T. Dishaw and D. M. Strong, "Extending the Technology Acceptance Model with Task Technology fit Constructs", Information and Management, vol. 36, no. 1, (1999), pp. 9-21.

[10] S. H. Jeon, N. L. Park and J. J. Lee, "Study on the Factors Affecting the Intention to Adopt Public Cloud Computing Service", Entrue Journal of Information Technology, vol. 10, no. 2, (2011), pp. 97112.

[11] K. B. Kahn, "Interdepartmental Integration: A Definition with Implications for Product Development Performance", Journal of Product Innovation Management, vol. 13, no. 2, (1996), pp. 137-151.

[12] M. Tims and A. B. Bakker, "Job Crafting: Towards a New Model of Individual Job Redesign", SA Journal of Industrial Psychology vol. 36, no. 2, (2010), pp. 1-9. 


\section{Authors}
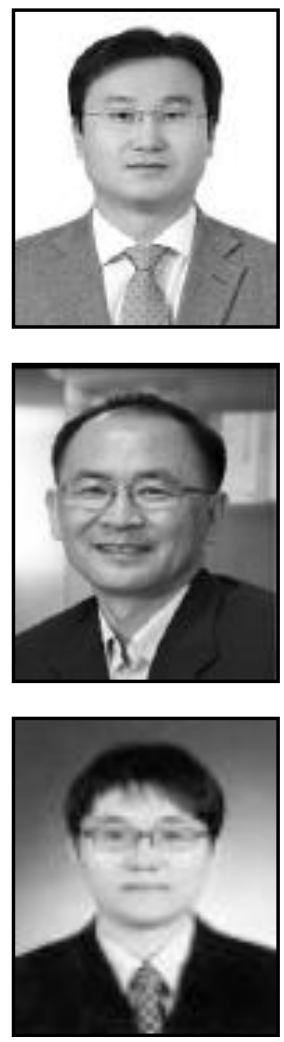

Kil-hwan Shin,

2000: Dept. Of MIS, Dankook Graduate School (M.D.) 2001: Dept. Of Information Science, Kookmin University (M.D.)

2013: Kookmin University, Graduate School of Business IT, (Ph.D.)

Research Area: Mobile Service, Cost Engineering

Choon Yeul Lee, (Corresponding Author)

1979: Dept. Of Industrial Engineering, Seoul National Univ.

1983: Dept. Of Business Administration, Seoul National Univ.

(M.D.)

1990: Univ. Of Michigan Computer\&IS(Ph.D.)

1994 Now: Dept. Of MIS, Kookmin University, Professor

Research Area: Database, Business Intellegence

Woon-heok Ko, (Corresponding Author)

2004: Kookmin Uiversity, Graduate School of Business IT, (M.D.)

2015: Kookmin University, Graduate School of Business IT, (Ph.D.)

2014 Now : Dept. of PMO, Public Procurement Service

Research Area: e-Government, ISP, Big Data 